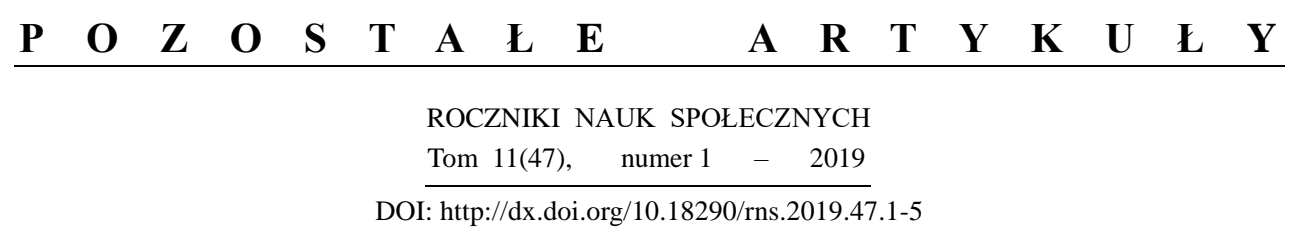

ŁUKASZ TOMCZAK

\title{
WYBORY DO SEJMIKU WOJEWÓDZTWA ZACHODNIOPOMORSKIEGO
}

Rywalizacja na regionalnej, samorządowej scenie politycznej wydaje się dla partii i ugrupowań politycznych nie mniej ważna od pozostałych wyborów. Sejmiki województw często określane są mianem regionalnych parlamentów. Stawką w wyborach są nie tylko stanowiska w regionalnej administracji, lecz także możliwość decydowania o przeznaczeniu środków z funduszy unijnych, których znaczna część rozdysponowana jest przez samorządy województw. Niniejszy artykuł podejmuje problematykę rywalizacji partii i ugrupowań politycznych $\mathrm{w}$ wyborach samorządowych na poziomie regionalnym w województwie zachodniopomorskim. Badaniami objęto wszystkie wybory do sejmiku w latach 1998, 2002, 2006, 2010, 2014 i 2018. Skupiono się na wynikach głosowania i wyborów, sytuacji powyborczej na regionalnym rynku politycznym, nie odnosząc się do przebiegu poszczególnych kampanii. Celem artykułu jest analiza wyników wyborów i będących ich efektem zmian na regionalnej scenie politycznej w ujęciu porównawczym. Przyjęto następujące pytania badawcze: Jakie wyniki uzyskiwały komitety wyborcze w kolejnych elekcjach? Jak proporcjonalny był podział mandatów? Jakie budowano koalicje powyborcze? Jaka była siła ugrupowań zwycięskich? W badaniu zastosowano metodę porównawczą ${ }^{1}$. Określając siłę partii i ugrupowań w sejmiku, posłużono się indeksami agregacji, rywalizacyjności oraz efektywnej liczby partii ${ }^{2}$. Dane dotyczące wyborów i wyników głosowania uzyskano z Państwowej Komisji Wyborczej.

Dr hab. ŁUKASZ ToMCZAK, prof. US - Instytut Politologii i Europeistyki, Uniwersytet Szczeciński; adres do korespondencji: ul. Krakowska 71/79, 71-017 Szczecin; e-mail: lukasz.tomczak@ usz.edu.pl; ORCID iD: https://orcid.org/0000-0002-6808-0364

${ }^{1}$ J. BAJER, Badania porównawcze w politologii. Zagadnienia metodologiczne, „Studia Politicae Universitatis Silesiensis" 8(2012), s. 28.

${ }^{2}$ R. HeRBUT, Systemy partyjne, w: Demokracje zachodnioeuropejskie. Analiza porównawcza, red. A. Antoszewski, R. Herbut, Wrocław: Wydawnictwo Uniwersytetu Wrocławskiego, 1997, s. 176-178. 


\section{OKRĘGI WYBORCZE, KOMITETY I KANDYDACI}

Województwo zachodniopomorskie powstało z gmin należących do dawnych województw szczecińskiego i koszalińskiego, części gmin województwa gorzowskiego (utworzono powiaty choszczeński i myśliborski) oraz pilskiego (utworzono powiat wałecki) i trzech gmin dawnego województwa słupskiego ${ }^{3}$. Od 2002 r. w skład województwa wchodziło 18 powiatów i trzy miasta na prawach powiatu.

W pierwszych wyborach do sejmiku województwa zachodniopomorskiego, w roku 1998, utworzono pięć okręgów wyborczych, w których wybierano 45 radnych. W skład okręgu I, w którym wybierano 12 radnych, weszły miasto Szczecin oraz powiat policki. W okręgu II, liczącym 7 mandatów, znalazło się miasto Świnoujście i powiaty: goleniowski, gryficki i kamieński. W skład okręgu III, liczącego 8 mandatów, weszły powiaty: białogardzki, drawski, kołobrzeski, świdwiński i wałecki. W okręgu IV, liczącym 8 mandatów, znalazło się miasto Koszalin oraz powiaty: koszaliński, sławieński i szczecinecki. W skład okręgu V, w którym wybierano 10 radnych, weszły powiaty choszczeński, gryfiński, myśliborski, pyrzycki i stargardzki. W kolejnych wyborach liczba okręgów wyborczych nie ulegała zmianie. Zmieniała się struktura okręgów pod względem należących do nich powiatów. Wprowadzona w 2002 r. zmiana granic okręgów wynikała $\mathrm{z}$ utworzenia nowego powiatu łobeskiego. Powstał on $\mathrm{z}$ pięciu gmin, wchodzących dotąd w skład powiatów: goleniowskiego, gryfickiego i stargardzkiego. Gminy te w wyborach 1998 r. wchodziły w skład okręgów II i V. Powiat łobeski wszedł w skład okręgu II. W 2002 r. zmniejszyła się do 30 liczba wybieranych radnych. Po tych zmianach okręg I liczył 8 mandatów, okręgi II, III i IV liczyły po 5 mandatów, a w okręgu $\mathrm{V}$ wybierano 7 radnych. W wyborach w latach 2006 i 2010 granica okręgów, jak i liczba przydzielonych im mandatów nie ulegały zmianie. W wyborach $2010 \mathrm{r}$. z dotychczasowego okręgu V wyłączono powiat choszczeński i włączono go do okręgu III, przenosząc jednocześnie jeden mandat $\mathrm{z}$ okręgu V do III. W kolejnych wyborach, w 2014 r., okręgi nie ulegały zmianie. $\mathrm{W}$ ostatnich wyborach przeniesiono powiat białogardzki z okręgu III do IV, jednocześnie przesuwając jeden mandat między tymi okręgami. Jedynym okręgiem, który pozostał bez zmian od pierwszych wyborów do sejmiku zachodniopomorskiego, był okręg I. Zmiany granic uniemożliwiają porównanie wyników wszystkich wyborów na poziomie okręgów. Jest to możliwe jedynie między wyborami w latach 2002 i 2006 oraz 2010 i 2014.

${ }^{3}$ Ł. TOMCZAK, Platforma idzie po władzę. Wybory samorzadowe w województwie zachodniopomorskim, w: Wybory do sejmików województw w 2006 roku, red. R. Alberski, M. Cichosz, Ł. Tomczak, Wrocław: Wydawnictwo MARINA 2010, s. 251. 
W wyborach do sejmiku województwa zachodniopomorskiego listy z kandydatami rejestrowały wszystkie ogólnopolskie komitety wyborcze głównych w danym czasie partii politycznych. W wyborach w 1998 r. 10 komitetów zarejestrowało 331 kandydatów na 37 listach wyborczych. W wyborach w 2002 r. o mandaty rywalizowało 542 kandydatów z 61 list zgłoszonych przez 14 komitetów. W kolejnych wyborach, w 2006 r., 10 komitetów zgłosiło 410 kandydatów na 45 listach. W wyborach w 2010 r. wzrosła liczba komitetów (do 12), natomiast spadła liczba kandydatów (do 377) i zgłoszonych list (do 44). W wyborach w 2014 r. o mandaty w sejmiku rywalizowało 412 kandydatów, zgłoszonych na 41 listach przez 11 komitetów wyborczych. W ostatnich wyborach, w 2018 r., zmniejszyła się liczba komitetów do 10, kandydatów - do 322, wzrosła liczba list (do 44). Zmniejszenie się liczby kandydatów w ostatnich wyborach mogło wynikać ze zmian w kodeksie wyborczym. W poprzednich wyborach komitety mogły umieszczać na listach dwukrotną liczbę kandydatów w stosunku do mandatów do zdobycia w okręgu. W 2018 r. można było umieścić liczbę kandydatów równą liczbie mandatów do zdobycia w okręgu, poszerzoną o dwie osoby.

\section{FREKWENCJA I GŁOSY NIEWAŻNE}

Liczba wyborców w pierwszych czterech elekcjach rosła i w roku 1998 wynosiła 1266 922, w 2002 - 1317766 , w 2006 - 1347748 i w 2010 1358618 osób. W kolejnych latach zmniejszała się, w 2014 r. było to 1352 418, a 2018 - 1316823 wyborców ${ }^{4}$. W wyborach do sejmiku województwa zachodniopomorskiego w 1998 r. frekwencja wynosiła 44,77\%. W wyborach w 2002 r. frekwencja obniżyła się $\mathrm{w}$ porównaniu $\mathrm{z}$ pierwszymi wyborami i wyniosła $43,6 \%$. Szczególnie niską frekwencję (33,21\%) odnotowano w okręgu I. W kolejnych dwóch elekcjach rosła w wyborach 2006 r., osiągając 45,57\%, a w wyborach 2010 r. - 45,95\% w skali województwa. Do wzrostu frekwencji w 2006 r. przyczynił się jeden okręg, pierwszy, obejmujący miasto Szczecin i powiat policki, w którym frekwencja wzrosła aż o 9,99 punkty procentowe. W pozostałych okręgach była mniejsza niż odnotowana w poprzednich wyborach. Jednak w okręgu I, mimo wzrostu, frekwencja była niższa niż w pozostałych okręgach. W wyborach w 2010 r. we wszystkich okręgach nastąpił wzrost frekwencji, z wyjątkiem okręgu I. Ogółem frekwencja w województwie wzrosła nieznacznie - o 0,38 punktu procentowego. W 2014 r. frekwencja obniżyła się w skali województwa i we wszystkich okręgach. Najniższą frekwencje odnotowano, podob-

\footnotetext{
${ }^{4}$ https://pkw.gov.pl/ [dostęp: 15.11.2018].
} 
nie jak w poprzednich wyborach, w okręgu I. Wybory w 2018 r. były pod tym względem wyjątkowe na tle dotychczasowych. Frekwencja była najwyższa w historii. W skali województwa, jak i we wszystkich okręgach przekroczyła $50 \%$, co do tej pory się nie zdarzyło. O tym, że częściej niż dotychczas w wyborach uczestniczyli mieszkańcy największego miasta w regionie, świadczy frekwencja w okręgu I. Okręg ten, największy pod względem liczby wyborców, odnotował najwyższą spośród wszystkich okręgów frekwencję - 52,6\%, co oznaczało wzrost w porównaniu z poprzednimi wyborami o 16,23 punktu procentowego $(44,62 \%)$. We wszystkich poprzednich wyborach okręg I zajmował pod względem frekwencji ostatnie miejsce.

Frekwencja w wyborach samorządowych zawsze była w województwie zachodniopomorskim niższa niż frekwencja na poziomie ogólnopolskim. W wyborach w 2018 r. zachodniopomorskie, na tle innych województw, pod względem frekwencji znalazło się na 14 miejscu. Niższa frekwencja była tylko w województwie warmińsko-mazurskim $(51,56 \%)$ i opolskim $(48,66 \%)^{5}$.

Odsetek głosów nieważnych utrzymywał się na wysokim poziomie aż do 2018 r. W wyborach w latach 2002 i 2006 był zbliżony, wyniósł odpowiednio $16,71 \%$ i $16,82 \%$. Zmniejszył się o nieco ponad 3,9 punktu procentowego w 2010 r. W 2014 r. wzrósł w porównaniu z poprzednimi wyborami aż o 6,54 punktu procentowego - do poziomu 19,46\% - i był najwyższy w historii. Jeżeli przyjrzymy się liczbie głosów nieważnych, to w 2002 r. odnotowano ich 95509 , a w wyborach w 2006 r. mniej - 74730 . Jednak w kolejnych wyborach liczba głosów nieważnych na poziomie województwa wzrosła. W 2010 r. oddano 80662 głosów nieważnych, a wyborach 2014 r. - aż 115 991. Liczba głosów nieważnych wzrosła wtedy we wszystkich okręgach. Ten wysoki odsetek głosów nieważnych charakteryzował zachodniopomorskie na tle pozostałych województw ${ }^{6}$. W wyborach w 2018 r. spadła zarówno liczba nieważnych głosów, jak i ich odsetek. Stosunkowo najmniejszą liczbę głosów nieważnych we wszystkich wyborach odnotowano w okręgu I. Okręg ten jest zdominowany przez elektorat wielkomiejski. Odsetek głosów nieważnych w wyborach w 2018 r. był w tym okręgu najniższy $(2,48 \%)$, podczas gdy w okręgach II, III, IV i V wynosił odpowiednio: $8,28 \% 9,00 \% 7,93 \%$ i 9,01\%. Z kolei najwyższy odsetek głosów nieważnych odnotowano w okręgu V. W wyborach w 2002 r. był to jedyny okręg, w którym odsetek głosów nieważnych przekroczył 20\%, a w kolejnych był wyższy od średniej wojewódzkiej.

\footnotetext{
${ }^{5}$ https://wybory2018.pkw.gov.pl. [dostęp: 15.11.2018].

${ }^{6}$ R. Alberski, Niekompetentny wyborca? Glosy nieważne $w$ wyborach do sejmików województw, w: Gra o regiony 2014. Wybory do sejmików województw, red. R. Alberski, M. Cichosz, Wrocław: Instytut Politologii Uniwersytetu Wrocławskiego 2017, s. 351.
} 


\section{WYNIKI GŁOSOWANIA I PODZIAŁ MANDATÓW}

W pierwszych wyborach do sejmiku województwa zachodniopomorskiego sukces odnotowała koalicja Sojusz Lewicy Demokratycznej (SLD), w kolejnych utrzymała się wysoka pozycja lewicy, już w postaci koalicji partii Sojusz Lewicy Demokratycznej i Unia Pracy (SLD-UP). W wyborach w 2006 r. nastąpił spadek popularności lewicy, a liderem wyborów w regionie została Platforma Obywatelska Rzeczypospolitej Polskiej (PO), uzyskując więcej głosów, ale o jeden mandat mniej niż otrzymała koalicja SLD-UP w 2002 r. Kolejne lata to dominacja w regionie PO zarówno pod względem uzyskanych głosów, jak i mandatów.

Tabela 1. Podział mandatów oraz poparcie dla komitetów uczestniczących w podziale mandatów do sejmiku województwa zachodniopomorskiego

\begin{tabular}{|c|c|c|c|c|c|c|c|}
\hline Komitet & & 1998 & 2002 & 2006 & 2010 & 2014 & 2018 \\
\hline \multirow[t]{3}{*}{$\mathrm{PO} / \mathrm{KO}$} & LG & \multirow{3}{*}{-} & 53315 & 179295 & 221804 & 153265 & 204979 \\
\hline & $\% \mathrm{G}$ & & 11,20 & 33,36 & 40,80 & 31,94 & 32,04 \\
\hline & LM & & 3 & 12 & 16 & 12 & 13 \\
\hline \multirow[t]{3}{*}{ PiS } & LG & \multirow{3}{*}{ - } & \multirow{3}{*}{ razem z $P O$} & 111905 & 101477 & 92590 & 171439 \\
\hline & $\% \mathrm{G}$ & & & 20,82 & 18,67 & 19,29 & 26,80 \\
\hline & LM & & & 7 & 5 & 6 & 11 \\
\hline \multirow{3}{*}{$\begin{array}{l}\text { SLD/ } \\
\text { LiD/ } \\
\text { SLD LR }\end{array}$} & LG & 200378 & 157968 & 99163 & 100672 & 56712 & 58110 \\
\hline & $\% \mathrm{G}$ & 39,00 & 33,17 & 18,45 & 18,52 & 11,82 & 9,08 \\
\hline & LM & 22 & 13 & 5 & 6 & 4 & 1 \\
\hline \multirow[t]{3}{*}{ PSL/PS } & LG & 47981 & 26445 & 51133 & 70460 & 98788 & 61940 \\
\hline & $\% \mathrm{G}$ & 9,33 & 5,55 & 9,51 & 12,96 & 20,58 & 9,68 \\
\hline & LM & 3 & 1 & 3 & 3 & 7 & 2 \\
\hline \multirow[t]{3}{*}{ Bezpartyjni } & LG & \multirow{3}{*}{-} & \multirow{3}{*}{ - } & \multirow{3}{*}{-} & \multirow{3}{*}{-} & 47318 & 87652 \\
\hline & $\% \mathrm{G}$ & & & & & 9,86 & 13,70 \\
\hline & LM & & & & & 1 & 3 \\
\hline \multirow[t]{3}{*}{ Samoobrona } & LG & \multirow{3}{*}{ razem z $P S$} & 91165 & 40623 & \multirow{3}{*}{-} & \multirow{3}{*}{-} & \multirow{3}{*}{-} \\
\hline & $\% \mathrm{G}$ & & 19,14 & 7,56 & & & \\
\hline & LM & & 7 & 3 & & & \\
\hline \multirow[t]{3}{*}{ LPR } & LG & \multirow{3}{*}{-} & 62997 & \multirow{3}{*}{-} & \multirow{3}{*}{-} & \multirow{3}{*}{-} & \multirow{3}{*}{-} \\
\hline & $\% \mathrm{G}$ & & 13,23 & & & & \\
\hline & LM & & 6 & & & & \\
\hline \multirow[t]{3}{*}{ AWS } & LG & 139649 & \multirow{3}{*}{-} & \multirow{3}{*}{-} & \multirow{3}{*}{-} & \multirow{3}{*}{-} & \multirow{3}{*}{-} \\
\hline & $\% \mathrm{G}$ & 27,18 & & & & & \\
\hline & LM & 13 & & & & & \\
\hline \multirow[t]{3}{*}{ UW } & LG & 62713 & & & & & \\
\hline & $\% \mathrm{G}$ & 12,20 & - & - & - & - & - \\
\hline & LM & 6 & & & & & \\
\hline $\mathrm{RP}, \mathrm{O}$ ” & LG & 27141 & & & & & \\
\hline & $\% \mathrm{G}$ & 5,28 & - & - & - & - & - \\
\hline & LM & 1 & & & & & \\
\hline
\end{tabular}

Źródło: https://pkw.gov.pl/; https://wybory2018.pkw.gov.pl. [dostęp:15.11.2018]; LG - liczba głosów, \%G procent głosów, LM - liczba mandatów. 
Najlepszy wynik PO odnotowała w wyborach 2010 r., po którym mogła samodzielnie rządzić regionie. W wyborach w 2014 r. Platforma zdobyła mniej głosów nie tylko od rekordowego poparcia z poprzednich wyborów, o około jedną czwartą, ale także od poparcia uzyskanego w 2006 r. Z kolei w ostatnich wyborach, 2018 r., Koalicja Obywatelska (KO), tworzona przez PO i partię Nowoczesna, w porównaniu z wynikiem PO z 2014 r. uzyskała o 33,74\% głosów więcej. Przy wyższej frekwencji PO zyskała nowych wyborców, ale wzrost procentowego udziału $\mathrm{w}$ głosach był niewielki (około 0,1 punktu procentowego). W przypadku Prawa i Sprawiedliwości (PiS) można zaobserwować systematyczny spadek liczby oddawanych głosów na listy tej partii w skali województwa w wyborach w latach 2006, 2010 i 2014. W ostatnich wyborach nastapił jednak znaczny wzrost. Listy PiS w wyborach w 2018 r. poparło około 85,16\% wyborców więcej niż w 2014 r. Pod względem procentowego udziału w głosach następował wzrost poparcia dla PiS w kolejnych wyborach w latach 2010, 2014 i 2018 r. W przypadku lewicy, po spadku poparcia między rokiem 2002 i 2006 oraz minimalnym wzroście w 2010 r., następował spadek liczby otrzymanych głosów i mandatów w kolejnych wyborach. Komitet SLD Lewica Razem (SLD LR) zdobył w 2018 r. około 29\% głosów, jakie przypadły na komitet SLD-UP w 1998 r. Podobnie zmniejszał się udział mandatów kontrolowanych przez partie lewicowe. Jednak poparcie uzyskane przez SLD i koalicje z jego udziałem w wyborach do sejmiku zachodniopomorskiego było zawsze wyższe od średniego poparcia dla tej partii w wyborach do sejmików w skali kraju. Od wyborów w 2002 do wyborów 2014 r. swój wynik systematycznie poprawiało Polskie Stronnictwo Ludowe (PSL) zarówno pod względem procentowego poparcia, jak i liczby otrzymanych głosów. Jednak w wyborach w 2018 r. nastąpił duży spadek poparcia dla ludowców oraz zmniejszyła się liczba kontrolowanych przez nich mandatów w sejmiku. Ludowcy otrzymali o 37,3\% głosów mniej niż w 2014 r., a liczba kontrolowanych przez nich mandatów obniżyła się z 7 do 2 . W przypadku PSL wyniki uzyskiwane w wyborach do sejmiku województwa zachodniopomorskiego były we wszystkich elekcjach niższe niż średnie poparcie tej partii w pozostałych województwach.

Zdarzały się przypadki deformacji wyniku. Na przykład w wyborach w roku 2002 komitet wyborczy „Wspólnota 2002” otrzymał 30019 głosów, czyli więcej niż PSL, jednak nie zdobył żadnego mandatu. Rozkład głosów w okręgach był korzystny dla ludowców, którzy otrzymali jeden mandat w okręgu drugim. Wyniki uległy znacznej deformacji w wyborach w 2006 r., gdy wprowadzono moż- 
liwość łączenia list w bloki przy przeliczaniu głosów na mandaty ${ }^{7}$. Wpłynęło to na podział mandatów w czterech na pięć okręgów. Dominowały dwa bloki: jeden utworzony wokół PO (PSL, Krajowa Partia Emerytów i Rencistów, PO), a drugi wokół PiS (LPR, PiS, Samoobrona RP). Blok z PO zdobył łącznie 15 mandatów, przy poparciu 45,3\% głosów, a blok utworzony wokół PiS - 10 mandatów, przy poparciu 33,09\% głosów. Gdyby podział mandatów odbywał się według starej ordynacji, PO zdobyłaby 13, PiS - 6, LiD - 7, a PSL i Samoobrona RP - po 2 mandaty. W wyniku łączenia list w bloki najwięcej utraciły lewica i PO, zyskały zaś PiS, PSL i Samoobrona. Zmiany w ordynacji doprowadziły do tego, że w sejmiku PiS otrzymało o dwa mandaty więcej niż LiD, zaś gdyby zachowano dotychczasowe zasady, miałoby o jeden mandat mniej.

\section{FORMOWANIE SIĘ WŁADZY W SEJMIKU}

W sejmiku województwa zachodniopomorskiego władzę sprawowały koalicje partii i ugrupowań. Po pierwszych wyborach, w 1998 r., zawiązano koalicję między SLD i Przymierzem Społecznym (PS). PS była koalicją utworzoną przez PSL, Unię Pracy, Krajową Partię Emerytów i Rencistów oraz Przymierze Samoobrona (w 2000 r. zmieniło nazwę na Samoobrona RP). Koalicja SLD i PS kontrolowała 25 mandatów na 45 . W tych wyborach, w ramach PS, mandat przypadł Andrzejowi Lepperowi, który kandydował z drugiego miejsca w okręgu III. Jedyny mandat dla Ruchu Patriotycznego „Ojczyzna” (RP „O”) otrzymał Marian Jurczyk, późniejszy Prezydent Szczecina, który zrzekł się mandatu pod koniec 1998 r. Marszałkiem sejmiku został Zbigniew Zychowicz (SLD), a przewodniczącym - Jerzy Mokrzycki (SLD). W trakcie tej kadencji doszło do zmian w składzie władz sejmiku. W 2000 r. miejsce Zbigniewa Zychowicza zajął Józef Faliński (SLD), a miejsce Jerzego Mokrzyckiego - Wojciech Długoborski (SLD), którego w 2001 r. zastąpił Karol Osowski (SLD). W trakcie kadencji zrzekli się mandatu Zbigniew Zychowicz (wraz z uzyskaniem mandatu senatora w wyborach uzupełniających w 2000 r.) oraz Wojciech Długoborski i Andrzej Lepper (w związku z uzyskaniem mandatu posła w $2001 \mathrm{r}$.) ${ }^{8}$.

Po wyborach w 2002 r. koalicję utworzyły SLD i Samoobrona RP, które w sumie kontrolowały 20 mandatów na 30 . Wybór marszałka sejmiku pokazał

7 J. MARSZAŁEK-KAWA, Wybory samorzadowe 2006 a kwestia nowelizacji samorzadowej ordynacji wyborczej, w: Samorząd terytorialny. Studium politologiczne, red. J. Marszałek-Kawa, Toruń: Wydawnictwo DUET 2007, s. 200-201.

${ }^{8}$ M. CZERwiŃSKI, Kampania i wyniki wyborów do sejmiku województwa zachodniopomorskiego w 2002 roku, w: Wybory samorzadowe w 2002 roku w Szczecinie, red. K. Kowalczyk, Szczecin: Wydawnictwo Naukowe Uniwersytetu Szczecińskiego 2003, s. 141. 
rysujący się konflikt w obrębie SLD, gdyż nie wybrano dotychczas sprawującego tę funkcję Józefa Falińskiego, lecz Zygmunta Meyera (SLD). Przewodniczącym sejmiku został Karol Osowski (SLD), a wiceprzewodniczącymi Czesława Nowak (Samoobrona RP), Sylwester Chruszcz (Liga Polskich Rodzin (LPR)) i Zygmunt Dziewguć (PSL). W trakcie kadencji w wyniku konfliktu między koalicjantami z zarządu odeszli działacze Samoobrony RP.

Po wyborach 2006 r. władzę w sejmiku przejęła koalicja PO i PSL. W sumie partie te zdobyły 15 mandatów na 30. Większość zapewnił radny Józef Faliński, który opuścił klub Lewicy i Demokratów (LiD) i został radnym niezależnym9 ${ }^{9}$. Funkcję przewodniczącego sejmiku sprawowali politycy Platformy, kolejno Michał Łuczak i Olgierd Geblewicz. W czasie kadencji zmieniał się także skład zarządu województwa. Marszałka Norberta Obryckiego (PO) w 2008 r. zastąpił Władysław Husejko (PO).

W wyborach w 2010 r. PO potwierdziła dominującą pozycję $\mathrm{w}$ regionie, zdobywając większość manatów w sejmiku, co pozwalało na samodzielne utworzenie zarządu województwa. Jednak zdecydowano się na kontynuację koalicji z PSL, które wypadło lepiej pod względem liczby głosów w porównaniu z poprzednimi wyborami, ale nie zwiększyło liczby kontrolowanych mandatów. Partie koalicyjne kontrolowały 19 mandatów. Tylko nieznacznie spadło poparcie dla PiS, zaś wynik SLD był podobny do uzyskanego przez koalicje LiD w poprzednich wyborach. Przewodniczącym sejmiku został Marek Tałasiewicz (PO), wiceprzewodniczącymi Jerzy Kotlęga (SLD), Kazimierz Drzazga (PiS) i Witold Ruciński (PSL). Marszałkiem województwa został Olgierd Geblewicz (PO) ${ }^{10}$.

W wyborach w 2014 r. po raz kolejny zwycięstwo odniosła PO, ale z wynikiem gorszym niż cztery latach wcześniej zarówno pod względem zdobytych głosów, jak i mandatów ${ }^{11}$. Na regionalnej scenie politycznej pojawił się nowy podmiot - komitet „Bezpartyjni” KWW Pomorze Zachodnie, założony m.in. z inicjatywy prezydenta Szczecina Piotra Krzystka, kandydującego na prezydenta Koszalina Artura Wezgraja oraz burmistrza Polic Władysława Diakuna ${ }^{12}$. Radną z tego ugrupowania została Maria Ilnicka-Mądry, wieloletnia dyrektor szpitala

\footnotetext{
${ }^{9}$ K. KowalczyK, Ł. TomcZaK, Wybory samorzadowe w Szczecinie w 2006 roku, Szczecin: Wydawnictwo Naukowe Uniwersytetu Szczecińskiego 2008, s. 142.

${ }^{10}$ M. Siedziako, Ł. TomCZAK, Platforma mimo wszystko. Wybory do sejmiku województwa zachodniopomorskiego, w: Gra o regiony. Wybory do sejmików województw w 2010 r., red. R. Alberski, M. Cichosz, K. Kobielska, Wrocław: Wydawnictwo REMAR, 2013, s. 311.

${ }^{11}$ K. KowAlCZYK, Pomorze Zachodnie - „bastion PO”? Wybory do Sejmiku Województwa Zachodniopomorskiego w 2014 rok, „Opuscula Sociologica” 2015, nr 3, s. 69.

12 A. WojtaszaK, Rola i znaczenie Bezpartyjnego Komitetu Wyborczego Wyborców Pomorze Zachodnie w wyborach do Sejmiku Województwa Zachodniopomorskiego w 2014 roku, „Acta Politica Polonica" 2016, nr 2, s. 68.
} 
w Szczecinie, która była już wcześniej radną sejmiku (w 1998 r.), wybraną z list Unii Wolności ${ }^{13}$. Utrzymano koalicję PO i PSL, jednak głosy ludowców były tym razem niezbędne do uzyskania większości. Partie koalicyjne kontrolowały 19 mandatów, w tym siedmiu radnych reprezentowało PSL. Zmienił się podział miejsc w zarządzie województwa. W poprzedniej kadencji, gdy PO kontrolowała większość mandatów, cztery miejsca przypadły tej partii, a jedno koalicjantowi. W nowym rozdaniu trzy miejsca przypadły PO, a dwa PSL. Marszałkiem sejmiku został ponownie Olgierd Geblewicz (PO), wicemarszałkiem Jarosław Rzepa (PSL). Przewodniczącą sejmiku została Teresa Kalina (PO), a wiceprzewodniczących wybrali radni pełniący tę funkcję w poprzedniej kadencji ${ }^{14}$.

W wyborach w 2018 r. najlepszy wynik uzyskała KKW Platforma, Nowoczesna Koalicja Obywatelska (KO). Podział mandatów nie pozwalał na utrzymanie władzy $\mathrm{w}$ regionie $\mathrm{w}$ oparciu wyłącznie o dotychczas współrządzące PO i PSL. Do większości zabrakło jednego mandatu. Rozwiązaniem było rozszerzenie koalicji o jednego radnego, wybranego list SLD Lewica Razem. W sumie nowa koalicja kontrolowała 16 mandatów. Współpracę z koalicją zapowiedzieli też Bezpartyjni Samorządowcy, co dawało dodatkowe wsparcie trzech mandatów. W Szczecinie reprezentujący to ugrupowanie prezydent Piotr Krzystek zerwał dotychczasową współpracę z PiS na rzecz współpracy z KO. Przewodniczącą sejmiku została reprezentująca Bezpartyjnych Samorządowców Maria IlnickaMądry. W wyborach kandydowała ona $\mathrm{z}$ okręgu I, w którym jedyny mandat $\mathrm{z}$ list Bezpartyjni zdobył Aleksander Doba, znany podróżnik. Zrezygnował on z objęcia mandatu, w jego miejsce (jako osoba $\mathrm{z}$ drugim w kolejności wynikiem na liście) mandat uzyskała Maria Ilnicka-Mądry. Marszałkiem został ponownie Olgierd Geblewicz (PO), wicemarszałkami Jarosław Rzepa (PSL), Tomasz Sobieraj (PO), a członkami zarządu Janusz Gromek (PO) i Stanisław Wziątek (SLD). Wiceprzewodniczącymi sejmiku wybrano Zbigniewa Chojeckiego (PO), Zygmunta Dziewgucia (PSL) i Teresę Kalinę (PO) ${ }^{15}$. Nie wybrano wiceprzewodniczącego z drugiego co do wielkości klubu radnych PiS.

${ }^{13}$ K. KowalczYK, Wybory samorzadowe w 2014 roku w Szczecinie, Szczecin: Wyd. Soft Vision 2015, s. 53.

${ }^{14}$ Ł. TOMCZAK, Bez zmian z mocniejszym odcieniem zieleni. Wybory do sejmiku województwa zachodniopomorskiego, w: Gra o regiony 2014. Wybory do sejmików województw, red. R. Alberski, M. Cichosz, Wrocław: Instytut Politologii Uniwersytetu Wrocławskiego 2017, s. 313.

15 http://www.sejmik.wzp.pl/aktualnosci/546-uchwaly-podjete-na-i-sesji-sejmiku-wojewodztwazachodniopomorskiego-23-listopada-2018.html [dostęp: 10.12.2018]. 


\section{PARTIE I UGRUPOWANIA POLITYCZNE W SEJMIKU}

Proporcjonalność wyborów zakłada, że partia powinna otrzymać zbliżony odsetek mandatów w stosunku do odsetka głosów otrzymanych w wyborach. Idealna proporcjonalność byłaby wtedy, gdyby liczby te były równe, czyli ugrupowanie otrzymałoby taki sam odsetek mandatów, jaki był odsetek głosów, które padły na jego listy. Pod względem proporcjonalnego podziału mandatów partia może być nadreprezentowana lub niedoreprezentowana. Rozmiar nadreprezentacji oblicza się, odejmując od odsetka uzyskanych mandatów odsetek uzyskanych głosów i dzieląc wynik przez odsetek uzyskanych głosów. Im bardziej wartość jest wyższa od 0 , tym większa jest nadreprezentacja mandatów dla danego ugrupowania; wartości ujemne świadczą o tym, że dany komitet uzyskał procentowo mniej mandatów niż głosów.

Tabela 2. Rozmiar nadreprezentacji w wyborach do sejmiku województwa zachodniopomorskiego

\begin{tabular}{|c|c|c|c|c|}
\hline \multicolumn{5}{|c|}{1998} \\
\hline SLD & AWS & UW & PS & $\mathrm{RP}, \mathrm{O}$ ” \\
\hline 0,38 & 0,17 & 0,20 & $-0,21$ & $-0,54$ \\
\hline \multicolumn{5}{|c|}{2002} \\
\hline SLD-UP & Samoobrona RP & LPR & PO-PiS & PSL \\
\hline 0,30 & 0,21 & 0,51 & $-0,10$ & $-0,40$ \\
\hline \multicolumn{5}{|c|}{2006} \\
\hline $\mathrm{PO}$ & $\mathrm{PiS}$ & $\mathrm{LiD}$ & PSL & Samoobrona RP \\
\hline 0,19 & 0,12 & $-0,09$ & 0,05 & 0,06 \\
\hline \multicolumn{5}{|c|}{2010} \\
\hline $\mathrm{PO}$ & PiS & SLD & PSL & - \\
\hline 0,31 & $-0,11$ & 0,08 & $-0,23$ & - \\
\hline \multicolumn{5}{|c|}{2014} \\
\hline $\mathrm{PO}$ & PSL & PiS & SLD LR & Bezpartyjni \\
\hline 0,25 & 0,13 & 0,04 & 0,13 & $-0,66$ \\
\hline $\mathrm{KO}$ & PiS & PSL & Bezpartyjni & SLD LR \\
\hline 0,35 & 0,37 & $-0,31$ & $-0,27$ & $-0,63$ \\
\hline
\end{tabular}

Dane: https://pkw.gov.pl/; https://wybory2018.pkw.gov.pl. [dostęp: 15.11.2018], obliczenia własne.

Wybory w 2006 r., mimo wprowadzenia łączenia list w bloki, były najbardziej proporcjonalne. W przypadkach uzyskania mniejszego odsetka mandatów 
niż głosów szczególną uwagę zwraca duże niedoreprezentowanie komitetu Bezpartyjni w 2014 r. oraz SLD Lewica Razem w wyborach w 2018 r. W przypadku wyborów z 2018 r. wystąpiła stosunkowo wysoka, w porównaniu z innymi elekcjami, nadreprezentacja dwóch partii o największym poparciu przy niedoreprezentowaniu wszystkich mniejszych formacji.

Indeks agregacji, iloraz odsetka miejsc kontrolowanych przez największą partię i liczby partii w organie kolegialnym służy do pomiaru pozycji najsilniejszej partii. Indeks rywalizacyjności pokazuje rozmiar przewagi partii zwycięskiej nad głównym rywalem do zwycięstwa. Określa się go stosunkiem odsetka głosów uzyskanych w wyborach przez ugrupowanie drugie do odsetka głosów uzyskanych przez partię wygrywającą wybory. Przy równowadze dwóch najsilniejszych partii wartość indeksu wynosi 1 . Im mniejsza wartość, tym mniejszy poziom rywalizacyjności i większa przewaga partii zwycięskiej. Indeks efektywnej liczby partii pozwala określić liczbę relewantnych podmiotów wraz z uwzględnieniem ich potencjału. Obserwując zmiany wartości, jakie przyjmuje ten wskaźnik, można określić, czy dany system zmierza w kierunku koncentracji, ustabilizowania czy rozproszenia. Koncentracja następuje przy zmniejszaniu się liczby relewantnych podmiotów lub wzrastania ich potencjału ${ }^{16}$.

Tabela 3. Agregacja, rywalizacyjność i efektywna liczba partii

\begin{tabular}{|l|r|r|r|r|r|r|}
\hline \multicolumn{1}{|c|}{ Wybory } & 1998 & 2002 & 2006 & 2010 & 2014 & 2018 \\
\hline \% mandatów dla największej partii & 48,89 & 43,33 & 40,00 & 53,33 & 40,00 & 43,33 \\
\hline Efektywna liczba partii & 2,90 & 3,46 & 3,87 & 2,76 & 3,66 & 2,96 \\
\hline Indeks agregacji & 9,78 & 8,67 & 8,00 & 13,33 & 8,00 & 8,66 \\
\hline Indeks rywalizacyjności & 0,70 & 0,58 & 0,62 & 0,46 & 0,60 & 0,83 \\
\hline
\end{tabular}

Dane: https://pkw.gov.pl/; https://wybory2018.pkw.gov.pl. [dostęp: 15.11.2018], obliczenia własne.

Indeks efektywnej liczby partii wzrastał w latach 1998, 2002 i 2006, ale w kolejnych wyborach (w 2010 r.) był najniższy w historii; ponownie wzrósł w wyborach 2014 r. Obserwując zmiany indeksów na przestrzeni sześciu elekcji, nie można wskazać wyraźnej tendencji. Wartość indeksu agregacji w województwie zachodniopomorskim utrzymała się na podobnym poziomie od wyborów 2002 r., z wyjątkiem wyborów w 2010 r., gdy większość mandatów w sejmiku

${ }^{16}$ Ł. TomczaK, Partie i ugrupowania polityczne $w$ wyborach do Sejmiku Województwa Zachodniopomorskiego, w: Geografia wyborcza Polski. Interpretacja postaw i zachowań obywateli, red. T. Koziełło, D. Szczepański, Rzeszów: Wydawnictwo Uniwersytetu Rzeszowskiego 2018, s. 246. 
przypadła komitetowi zwycięskiej PO, a także zmniejszyła się liczba komitetów uczestniczących w podziale mandatów. Średni poziom agregacji wszystkich województw wzrósł z 8,45 (2006) do 10 (2010) punktów. Województwo zachodniopomorskie zaliczano wtedy do grupy pięciu województw o najsilniejszym potencjale lidera regionalnego rynku, w tym wypadku $\mathrm{PO}^{17}$. Jednak w pozostałych wyborach wartość indeksu dla badanego województwa była zbliżona. Jeśli chodzi o poziom rywalizacyjności, wyraźnie wyróżniają się wybory w 2010 r. i przewaga, jaką $w$ tym czasie osiągnęła $w$ regionie PO. Jednak w kolejnych wyborach wartość indeksu rywalizacyjności rosła, zmniejszała się przewaga partii zwycięskiej.

Tabela 4. Odsetek głosów oddanych na listy dwóch komitetów o najwyższym poparciu

\begin{tabular}{|l|c|c|c|c|c|c|}
\hline \multicolumn{1}{|c|}{ Wybory } & 1998 & 2002 & 2006 & 2010 & 2014 & 2018 \\
\hline Poparcie dla zwycięskiego komitetu & 39,00 & 33,17 & 33,36 & 40,80 & 31,94 & 32,04 \\
\hline Poparcie dla drugiego komitetu & 27,18 & 19,14 & 20,82 & 18,67 & 20,58 & 26,80 \\
\hline Łącznie & 66,18 & 52,31 & 54,18 & 59,47 & 52,52 & 58,84 \\
\hline
\end{tabular}

Dane: https://pkw.gov.pl/; https://wybory2018.pkw.gov.pl. [dostęp: 15.11.2018], obliczenia własne.

Nie wzrastał poziom koncentracji głosów na zwycięzcy, a także na dwóch komitetach o najwyższym poparciu. Poziom poparcia dla zwycięskiego komitetu rósł między rokiem 2002 a 2010, ale w 2014 r. ta tendencja się odwróciła i był najniższy spośród wszystkich elekcji. W 2014 r. najniższy był poziom poparcia dla ugrupowania zwycięskiego.

\section{ZAKOŃCZENIE}

W sejmiku województwa zachodniopomorskiego cztery partie, PO, PiS, SLD i PSL, samodzielnie albo w koalicjach wyborczych uzyskiwały mandaty we wszystkich wyborach od 1998 roku. W pierwszych dwóch elekcjach najlepsze wyniki uzyskiwała lewica, stając się główną siłą koalicji rządzących. Zmiana na pozycji najsilniejszego gracza w regionie nastąpiła $2006 \mathrm{r}$. W tych i w kolejnych

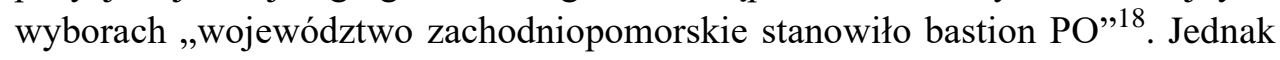

17 M. Cichosz, Czterobarwne uktadanki. Podsumowanie strategii podmiotów politycznych w wyborach do sejmików województw w 2010 roku, w: Gra o regiony. Wybory do sejmików województw w 2010 r., red. R. Alberski, M. Cichosz, K. Kobielska, Wrocław: Wydawnictwo REMAR 2013, s. 328.

${ }^{18}$ K. KowalcZYK, Pomorze Zachodnie, s. 63. 
wybory 2014 r. zaznaczyły się wyraźnym spadkiem poparcia dla tej formacji. W wyborach 2018 r. poparcie dla KKW Platforma, Nowoczesna Koalicja Obywatelska wzrosło niewiele, o 0,1 punktu procentowego. Jednocześnie od wyborów w 2010 r. rósł odsetek wyborców popierających PiS, głównego konkurenta rządzącej koalicji. Należy zauważyć zmniejszającą się w tym czasie różnicę w otrzymywanym poparciu między PiS a PO; wynosiła ona odpowiednio w kolejnych wyborach 22,13, 11,36 i 5,24 punktu procentowego. Oznacza to, że choć PO utrzymywała przewagę nad PiS, to zmniejszał się dystans dzielący obie formacje.

Ugrupowania zwycięskie uzyskiwały najczęściej znaczną przewagę mandatów nad pozostałymi. Tylko w jednym przypadku, w wyborach w 2010 r., przewaga ta umożliwiała utworzenie jednopartyjnego zarządu. W praktyce nie miało to miejsca, a władzę sprawowały różne koalicje budowane na porozumieniu między partiami. Jedynie w 2006 r. utworzona koalicja PO i PSL uzyskała większość dzięki przejściu na jej stronę radnego wybranego z list lewicy.

\section{BIBLIOGRAFIA}

AlBERSKI R., Niekompetentny wyborca? Głosy nieważne w wyborach do sejmików województw w: Gra o regiony 2014. Wybory do sejmików województw, red. R. Alberski, M. Cichosz, Wrocław: Wydawca Instytut Politologii Uniwersytetu Wrocławskiego 2017, s. 351.

BAJER J., Badania porównawcze w politologii. Zagadnienia metodologiczne, „Studia Politicae Universitatis Silesiensis" 8(2012), s. 28.

Cichosz M., Czterobarwne układanki. Podsumowanie strategii podmiotów politycznych w wyborach do sejmików województw w 2010 roku, w: Gra o regiony. Wybory do sejmików województw w 2010 r., red. R. Alberski, M. Cichosz, K. Kobielska, Wrocław: Wydawnictwo REMAR 2013, s. 328.

CZERWIŃSKi M., Kampania i wyniki wyborów do sejmiku województwa zachodniopomorskiego w 2002 roku, w: Wybory samorządowe w 2002 roku w Szczecinie, red. K. Kowalczyk, Szczecin: Wydawnictwo Naukowe Uniwersytetu Szczecińskiego 2003, s 141.

Herbut R., Systemy partyjne, w: Demokracje zachodnioeuropejskie. Analiza porównawcza, red. A. Antoszewski, R. Herbut, Wrocław: Wydawnictwo Uniwersytetu Wrocławskiego, 1997, s. $176-178$.

KowAlCZYK K., Pomorze Zachodnie - „bastion PO”? Wybory do Sejmiku Województwa Zachodniopomorskiego w 2014 roku, ,Opuscula Sociologica” 2015, nr 3, s. 63.

KowAlCZYK K., Wybory samorządowe w 2014 roku w Szczecinie, Szczecin: Wyd. Soft Vision 2015.

Kowalczyk K., TOMCZak Ł., Wybory samorządowe w Szczecinie w 2006 roku, Szczecin: Wydawnictwo Naukowe Uniwersytetu Szczecińskiego 2008.

MARSZAŁEK-KAWA J., Wybory samorządowe 2006 a kwestia nowelizacji samorządowej ordynacji wyborczej, w: Samorząd terytorialny. Studium politologiczne, red. J. Marszałek-Kawa, Toruń: Wydawnictwo Adam Marszałek 2007, s. 200-201.

Siedziako M., TomczaK Ł., Platforma mimo wszystko. Wybory do sejmiku województwa zachodniopomorskiego w: Gra o regiony. Wybory do sejmików województw w 2010 r., red. R. Alberski, M. Cichosz, K. Kobielska, Wydawnictwo REMAR, Wrocław 2013, s. 311. 
TOMCZAK Ł., Bez zmian z mocniejszym odcieniem zieleni. Wybory do sejmiku województwa zachodniopomorskiego w: Gra o regiony 2014. Wybory do sejmików województw, red. R. Alberski, M. Cichosz, Wrocław: Instytut Politologii Uniwersytetu Wrocławskiego 2017, s. 313.

TomCZAK Ł., Partie i ugrupowania polityczne w wyborach do Sejmiku Województwa Zachodniopomorskiego, w: Geografia wyborcza Polski. Interpretacja postaw i zachowań obywateli, red. T. Koziełło, D. Szczepański, Rzeszów: Wydawnictwo Uniwersytetu Rzeszowskiego 2018, s. 246.

TomczaK Ł., Platforma idzie po władzę. Wybory samorządowe w województwie zachodniopomorskim, w: Wybory do sejmików województw w 2006 roku, red. R. Alberski, M. Cichosz, Ł. Tomczak, Wrocław: Wydawnictwo MARINA 2010, s. 251.

WojtAsZaK A., Rola i znaczenie Bezpartyjnego Komitetu Wyborczego Wyborców Pomorze Zachodnie w wyborach do Sejmiku Województwa Zachodniopomorskiego w 2014 roku, „Acta Politica Polonica” 2016, nr 2, s. 68.

\section{WYBORY DO SEJMIKU WOJEWÓDZTWA ZACHODNIOPOMORSKIEGO}

\section{Streszczenie}

Artykuł prezentuje wyniki badań dotyczących rywalizacji w wyborach samorządowych na poziomie regionu. Analiza odnosi się do wyników głosowania i wyborów do sejmiku województwa zachodniopomorskiego w sześciu kolejnych elekcjach. Badaniami objęto między innymi frekwencję, zmiany poparcia dla komitetów wyborczych i podział mandatów. Skupiono się na partiach, które albo samodzielnie, albo w koalicjach uzyskiwały mandaty w sejmiku. W badanym okresie najwyższe poparcie wyborcze osiągał do roku 2006 Sojusz Lewicy Demokratycznej, a w kolejnych wyborach Platforma Obywatelska RP. Województwo charakteryzowało się niższą frekwencją od średniej krajowej. W wyborach większe poparcie niż średnie w kraju uzyskiwały ugrupowania lewicy oraz Platforma Obywatelska RP.

Słowa kluczowe: wybory samorządowe; partie polityczne.

\section{ELECTIONS TO THE REGIONAL COUNCIL OF THE WEST POMERANIAN VOIVODESHIP}

S u m m a r y

The article presents the research of the effects of rivalry in local government elections at the regional level. The analysis concerns the results of voting and elections to the Regional Council of the West Pomeranian Voivodeship in six subsequent elections. The study includes factors such as: attendance, changes in support for electoral committees and the distribution of seats. The main focus was put on the parties that obtained seats in the Regional Council - either independently or within coalitions. In the analysed period, the Democratic Left Alliance (SLD) obtained the highest electoral support until 2006, but in the following elections the highest support belonged to the Civic Platform (PO). The West Pomeranian Voivodship noted lower turnout than the national average attendance. Leftist parties and the Civic Platform gained above average support in West Pomerania than on the country level.

Key words: local government elections; political parties. 